\title{
Teaching Writing Skills
}

\author{
Atherunnisa N Najma \\ M.A., M.Phil. \\ Asst Prof. in English \\ Govt Arts College \\ Bengaluru, India \\ nnajma29@yahoo.com
}

\begin{abstract}
This paper is based on my M.Phil research Project "A Discoursal Approach To Teaching Writing." Seven essays were analyzed using the discourse analysis approach to identify the discourse pattern, functions and relations.

The essays were considered in rhetorical terms and they represented different modes of writing - First person Narrative, public speech, personal, descriptive, Biographical and two Argumentative essays.

The discourse organization was studied and found important features, common at three levels. (a) Macro level - Patterns situation - problem - solution - evaluation (b) Micro level - functions Elaboration, Evaluation Inference and summing up (c) Micro level- relations condition - consequence, cause - effect, reason - result, contrast, question - answer and claim - counterclaim.
\end{abstract}

These findings showed that certain discourse features were used in similar ways by writers to structure and organization texts irrespective of what genre they belong to. 
On the basis of the findings, two types of tasks were designed at the above mentioned three levels. Tasks that help the student (a) To identify the discourse features (b) To develop their ability to produce coherent writing involving the use of these features.

The trying out of selected tasks showed that the tasks were feasible and helpful. Though some of the students had problems initially in comprehending, they could perform the tasks quite successfully once explanations were given and when content was given than otherwise.

Keywords: Discourse, Teaching-Writing Approach, Micro Level Functions, Micro Level Patterns, Micro Level Relations

Introduction:

This paper is based on my M.Phil. research project "A Discoursal Approach To Teaching Writing" . The main aim of this research was to analyze the seven essays prescribed for study for the first year students in order to identify discourse features like patterns, functions and relations which are frequently used in writing. The findings of this analysis was used to design tasks to teach students some aspects of writing.

Let me first define what is discourse and discourse analysis. Discourse is generally defined as language use which performs an act of communication and refers to larger units of language such as paragraphs, conversations and interviews. And 'Discourse analysis is concerned with the way language functions whether it is spoken or written.

The seven essays selected were:

1. The Canker of Untruth

M.K. Gandhi

2. Freedom and License

Jawaharlal Nehru

3. Student Mobs

J.B. Prestly 


$\begin{array}{llll}\text { 4. Vanishing Animals } & - & \text { Gerald Durrel } \\ \text { 5. A Layman looks at science } & - & \text { Raynard B. Fosdick } \\ \text { 6. } & \text { Can we afford to keep open minds? } & - & \text { Bertrand Russel } \\ \text { 7. } & \text { Mother Teresa } & - & \text { John Frazer }\end{array}$

The analysis was at three levels.

a) Micro level - patterns

b) Micro level - functions

c) Micro level - relations.

The analysis at the Macro level in terms of patterns was based on Heoy's Model.

Situation

Problem:

Solution/

(Response):

Result /

Evaluation:

Micro-level Functions: The functions considered were Elaboration, Evaluation, Inference and Summing up.

1. Elaboration could be done by: (a) example (b) anecdotes (c) Explanation

Example: The questions about which you should have an open mind depends upon your age and your occupation. It is no use perpetually reconsidering the decisions that have determined the framework of your life.

A young man let us say, is in doubt as to whether he shall become a doctor or a lawyer, and until the moment when a decision becomes necessary he does well to weigh the pros and cons carefully. But when he has decided, no purpose whatever is served by asking himself once a day, or once a month, or once a year, whether the opposite decision would not 
have been wiser. Even this however cannot be said absolutely. (Can we afford to keep open minds? P-31)

(b) Ancedote: I am anxious for people to know the greatness of the poor, she says. "I once went to a Hindu family which had been starving and brought them rice. Before I knew it, the mother had divided it and given half to the Muslim family next door. She said, "They are just as hungry as we are". "I believe we need the poor as much they need us. We are better for being in contact with them". (Mother Theresa - P - 36)

(c) Explanation by details: There is something else, just as bad, perhaps even worse, and evidence of it is amply supplied to us by TV camera and mikes. What we see in these students faces illuminated by burning cars and bonfires of books is not the glow of political enthusiasm but a frenzied delight in destruction. Whatever country or party they may be demonstrating for or against, what really impresses them is an urge towards violent demolition. (Student Mobs - P - 12)

2. Evaluation: An opinion is expressed and an assessment is made which is either positive or negative.

eg: One of the scientists who played a leading role in the development of the atomic bomb said to the newspaper - men: "A scientist cannot hold back progress because of fears of what the world will do with his discoveries". What he apparently impled was that science has no responsibility in the matter, and it will plunge ahead in the pursuit of truth even if the process leaves the world in dust and ashes.

Is that the final answer? Is there no other answer? Frankly as a layman, I do not know. Off hand, this disavowal of concern seems callous and irresponsible. But we may be facing a situation where no other answer is realistic or possible. To ask the scientists to foresee the use - the good or evil of the use - to which his results may be put is doubtless beyond the realm of 
the attainable. Almost any discovery can be used for either social or anti-social purposes. (A Layman Looks at Science P - 28)

3. Inference: The writer draws a conclusion logically on the basis of what had been said. eg: The towering enemy of mankind is not science but war. Science merely reflects the social forces by which it is surrounded. When there is peace, science is constructive, when-there is war, science is perverted to destructive ends. The weapons which science gives us do not necessarily create war, they make war increasingly more terrible, until now it has brought us to the doorstep of doom.

Our main problem therefore is not to curb science, but to stop war - to substitute law for force and international government for anarchy in the relations of one nation with another. (A Layman Looks at Science P - 29)

4. Summing up: The writer summarizes or relates briefly what had been said.

eg: As mankind increases year by year, and as he spreads farther over the globe burning and destroying, it is small comfort to know that there are certain private individuals and some institutions who consider that the work of trying to save and give sanctuary to these harried animals is of some importance. It is important work for many reasons, but perhaps the best of them is this, man for all his genius cannot create species, nor can he recreate one he has destroyed. There would be a dreadful outcry if any one suggested obliterating, say, the Tower of London, and quite rightly so; yet a unique and wonderful species of animal which has taken hundreds of thousands of years to develop to the stage we see today can be snuffed out like a candle without more than a handful of people raising a finger or a voice in protest.

So, until we consider animal life to be worthy of the consideration and reference we bestow upon old books and pictures and historic monuments, there will always be the animal refugee living a precarious life on the edge of extermination dependent for existence on the charity of a few human beings (Vanishing Animals P - 26) 


\section{Micro level - Relations:}

The relations considered were (i) reason - result (ii) condition - consequence (iii) cause - effect (iv) contrast (v) question - answer (vi) claim counterclaim

Result : (i) Sometime ago I was watching what must be the strangest group of refugees in this country, strange

Reason : because they did not come here for the usual reasons, driven by either religious or political persecution from their own country (Vanishing Animals, P - 21)

Condition: (ii) If there is mental disintegration in the body politc

Consequence: Obviously it affects every limb of it. (Freedom and Licence P - 6)

Effect: (iii) Unfortunately, the Pere David deer and the white - tailed gnu are not the only creatures in the world that are nearly extinct. The list of creatures that have vanished altogether, and others that have almost vanished, is a long and melancholy one.

Causes: As man has spread across the earth he has wrought the most terrible havoc among the wind life by the callous and stupid introduction of enemies where there were no enemies before (Vanishing Animals P - 75)

(iv) We had that tradition in the good old days, a student then being invariably known as a brahmachari.

Here it is not cause - effect but effect - cause

Contrast : But in these days we have child marriages, a thing practically unknown in England. (The Canker of Untruth P - 1)

Questions :(V) Is that the final answer? Is there no other answer? Answer: Frankly as a layman, I do not know (A Layman Looks at Science, P - 28) Claim: (VI) It may be said that a mind perpetually open will be perpetually vacant. Counterclaim : It is none the less clear that it would be disastrous for the mind to be in no degree open. (Can we Afford to keep Open Minds? P - 30) 
Findings:

When seven essays were considered in rhetorical terms they represented different modes of writing -

(i) 'The Canker of Untruth' - First Person Narrative.

(ii) 'Freedom and Licence' - Public Speech.

(iii) ‘Student Mobs’ - Personal Essay

(iv) 'Vanishing Animals' - Descriptive Essay.

(v) 'A Layman Looks at Science' - Argumentative Essay.

(vi) ‘Can We Afford to Keep Open Minds?' - Argumentative Essay.

(vii) 'Mother Teresa' - Biographical Sketch.

But when their discourse organization was studied, we found that there were important features which were common at all the three levels.

(a) Five essays show the macro pattern, situation - problem - solution - evaluation, though there are some variations which the writers used and may be called as "Unitary" functions like categorization, enumeration, narration and description.

(b) There were certain functions of the binary kind that occur frequently. These were elaboration, evaluation, inference and summing up.

(c) There were certain relations of the binary kind that occur frequently. These were condition consequence, cause-effect, reason-result, contrast, question-answer and claimcounterclaim.

These findings therefore showed that certain discourse features were used in similar ways by writers to structure and organize texts irrespective of what genre they belong to.

Teaching and writing had focussed mainly on the use of appropriate vocabulary items and grammatical patterns but in recent years there was a realization that this is not adequate 
and that discourse structure and organization should be a major component in the teaching of writing.

The findings of this analysis were used (a) to create in the students an awareness of the frequently used discourse features and (b) to help the students to use some of these features to organize their writing. And it was useful because the seven essays were prescribed and they were required to read and write on them.

Tasks Designed: Using the findings of this analysis, two types of writing tasks were designed.

(i) Tasks which aimed at helping the students to identify the discourse features.

(ii) Tasks which helped the students to develop their ability to produce coherent writing involving the use of these features.

At the macro level - pattern, some of the tasks designed were (i) to identify the pattern, situation - problem - solution - evaluation from the excerpt given (2) the pattern was jumbled and asked them to arrange it. (3) Passages were given where one part was missing and were asked to identify and write few sentences to fill up the gap.

Micro level - Functions: With examples functions were explained with the linking expressions. An excerpt was given without the linking expressions and were asked to fill it choosing the appropriate linking expressions. (2) sentences were given and were asked to elaborate, evaluate and sum it up.

Micro level relations: (1) relations were jumbled and matching exercises were given (2) Only one of the two parts of sentences were given and were asked to write the other part and complete the sentence.

Trying out of the tasks: 
The feasibility of the tasks designed were tested by trying out some of them in I year degree classes. The colleges chosen were Maharani's Arts college for Women (a government college) and VasaviVidyaNiketan College for Women (a private college)

In M.A.C.W. the class was I year B.A. and the tasks chosen was on functions. The duration of the class was 60 minutes and the total number of students was 15 .

In V.V.N.C.W. the class was I year B.Com. and the task chosen was on relations. The duration of the class was 55 minutes and the total number of students was 48 .

Conclusion: The trying out of selected tasks focusing functions and relations showed that the tasks were feasible and helpful. Though some of the students had problems initially in comprehending what they were required to do, they performed the tasks quite successfully once explanations were given. A more specific finding was that in production tasks the students performed better when given the content than otherwise.

Students in our classrooms are mostly used to the lecture mode where they passively listen to the teacher and are hardly given writing tasks. Though the tasks designed were totally unfamiliar to the students it was found that students do respond positively to them.

The findings of such an analysis could be used to design courses for teaching writing to students at different levels. The tasks designed for such courses could be tried out more extensively and modified depending on the students' responses. 


\section{References}

Brander .L.(ed), (1956), The Way We Go (A prose select for degree students) London:

Oxford University Press.

Brown.G. \&Yule.G., (1983), Discourse Analysis Cambridge: Cambridge University Press

Byrne, Donn., (1979), Teaching Writing Skills Harlow : Longman

Close R.A., (1984), The English We Use Hyderabad:Orient Longman Limited (Ninth Indian Impression)

Coe.N. \&Rycroft.R., (1983), Writing Skills A problem - solving approach Teacher's Book Cambridge: Cambridge University Press.

Cook, Guy., (1989), Discourse Oxford: Oxford University Press.

Coulthard.M., (1977), An Introduction to Discourse Analysis London: Longman.

Crombie.M, (1985), Discourse and Language Learning: A Relational Approach to Syllabus Design. Oxford: Oxford University Press

Crombie.W, (1985), Process and Relation in Discourse and Language Learning Oxford: Oxford University Press

Editorial Committee, (1977), An Anthology of Prose Bangalore: Bangalore University Editorial Committee, (1992), An Anthology of English Essay Poems and Short Stories (for I

Year B.A., B.Sc., B.Com., degree Courses) Bangalore: Bangalore University

Halliday M.A.K. \&Hasan.R., (1976), Cohesion In English London: Longman.

Hamp-Lyonds L. \&Heasley.B., (1987), Study Writing (A Course In Written English for Academic and Professional Purposes). Cambridge: Cambridge University Press. Hedge .T., (1988), Writing Oxford: Oxford University Press.

Hoey, Michael, (1983), On the Surface of Discourse London: George Allen and Unwin. McCarthy, M., (1991), Discourse Analysis for Language Teachers Cambridge: Cambridge University Press 
McCarthy, M. \&Carter.R., (1994), Language as Discourse - Perspectives for Language Teaching London: Longman.

Menon.K.P.K., (1973), Selected Prose for Degree Classes Madras: Macmillan India Limited.

Pincas .A., (1982), Teaching English Writing London: Macmillan Publishers Limited.

Quirk .R. et al, (1985), A Comprehensive Grammar of the English LanguageLondon: Longman.

Quirk .R., (1986), Words at Work Lectures on Textual Structure Singapore: Singapore University Press.

Raimes .A., (1983), Techniques In Teaching Writing Oxford : Oxford University Press

Raj Sundar.C.R. (ed), (1986), Selected English Essay Bangalore: Subhas Publications.

Richards., Platt J. \& Weber H. (ed), (1985), Longman Dictionary of Applied Linguistics Harlow: Longman.

Stern H.H., (1983), Fundamental Concepts of Language Teaching Oxford: Oxford University Press.

Van Dijk.T.A. (1977), Text and Context London : Longman.

Widdowson H.G., (1978), Teaching Language as Communication Oxford: Oxford University Press.

Widdowson H.G., (1979), Explorations in Applied Linguistics - 1 Oxford: Oxford University Press.

Widdowson H.G., (1980), Reading and Thinking in English, Concepts in Use, Exploring Functions, Discovering Discourse, Discourse in Action.

Widdowson H.G., (1984), Explorations in Applied Linguistics - 2 Oxford: Oxford University Press.

Wilte .R., (1984), Writing (Advanced) Oxford: Oxford University Press. 
White Ronald .V., (1980), Teaching Written English London: Hienemann Educational Books. 